Our Nature (2011) 9: 138-145

\title{
Snow Leopard (Uncia uncia), Prey Species and Outreach in Langtang National, Park, Nepal
}

\author{
M.K. Chalise \\ Central Department of Zoology, Tribhuvan University, Kathmandu, Nepal \\ E-mail:mukesh57@hotmail.com
}

Received: 19.10.2011, Accepted: 21.11.2011

\begin{abstract}
Presence of snow leopard (Uncia uncia) in Langtang National Park was obscure till 2003. It was confirmed by a research team trained for the wildlife biology in the field. Along with the study of ecology and behavior of snow leopard sufficient effort were made to generate data on pre species. The study also dealt with threat perceived for the leopard survival while basic unit of conservation- local outreach programs were also initiated.
\end{abstract}

Key words: Snow leopard, Langtang, prey species, threats, outreach.

\section{Introduction}

There have been reports of Snow Leopard (Uncia uncia) presence in the Langtang National Park (LNP), but the confirmation of its survival in recent years is lacking. Green (1982) reported that he noticed the existence of Snow Leopards during the expedition in LNP especially near the highland snow-fed lake Gosainkunda (3900 $\mathrm{m})$ and Langsisa plateau $(4540 \mathrm{~m})$. However, local people, herders and irregular investigators frequently revealed this endangered and protected species presence in the area. The fresh tracks (pawmarks) and cattle carcass killed by Snow Leopard in this region were recorded near the river plain at Kyanjing village $(3950 \mathrm{~m})$ that stimulate regular observation and monitoring it (NAHSON, 2003; Chalise et. al., 2004). Confirmation for detail needed and studied focusing on Snow Leopard ecology and behavior pattern in this National Park (Fig. 1). Realizing this need, studies were carried out in 2003-2004 spending $769 \mathrm{~h}$ scattered in 137 days and monitored during successive years around Langtang valley across the Kyanjing area.

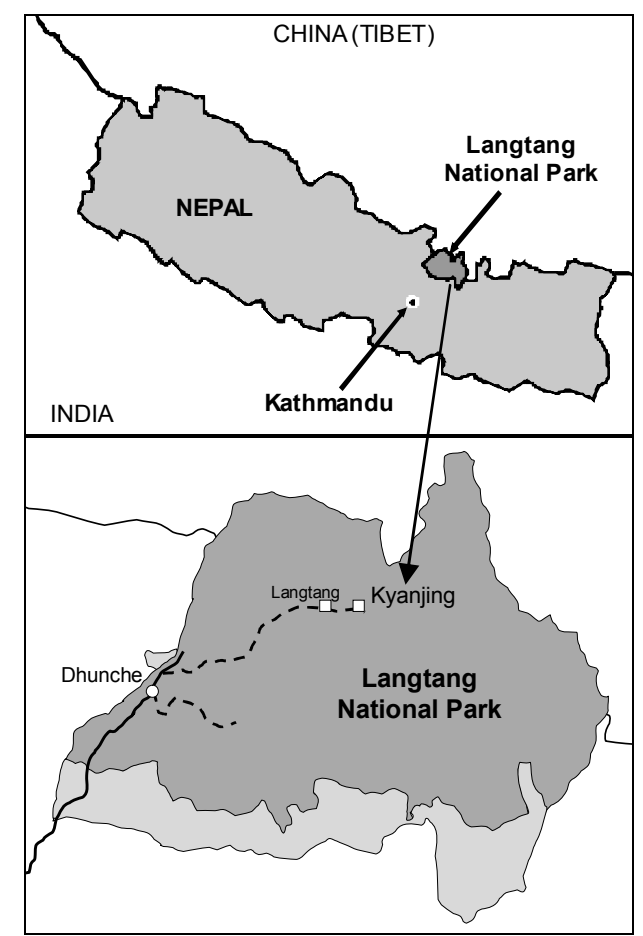

Figure 1. Langtang National Park, Nepal and main study area. 


\section{M.K. Chalise / Our Nature (2011) 9:138-145}

The Langtang valley (between the latitudes $28^{\circ} 11^{\prime} 87.5^{\prime \prime}$ to $28^{\circ} 12^{\prime} 28.6^{\prime \prime} \mathrm{N}$ and longitude $85^{\circ} 27^{\prime} 31.6^{\prime \prime}$ to $\left.85^{\circ} 42^{\prime} 16.9^{\prime \prime} \mathrm{E}\right)$ lies north of capital city Kathmandu along the Langtang river to the northern Himalayan range bordering with Tibet (China) in the central region of Nepal. The elevation varies from 3000 to $5125 \mathrm{~m}$. The park represents a meeting point between Indo-Malayan and paleartic realms and holds a rich biodiversity (DNPWC, 2002). LNP is the second largest mountain National Park established in 1976, which covers $1710 \mathrm{~km}^{2}$ in three districts viz., Rasuwa, Nuwakot and Sindhupalchowk of Bagmati zone in Nepal. LNP recorded 46 species of mammals and its expansive high meadow provides summer habitat for numerous ungulate species including those typical of the area, such as musk deer (Moschus chrysogaster) and Himalayan Thar (Hemitragus jemlahicus). In the different elevation, the park is harboring the populations of Red Panda (Ailurus fulgens), Himalayan Black Bear (Selenarctos thibetanus), Clouded Leopard (Neofelis nebulosa), Ghoral (Nemorhaedas goral), Wild Dog (Canis alpinus), Pika (Ochotona species) and three species of monkeys viz., Rhesus Monkeys, Hanuman Langur and Assamese Monkeys (Macaca assamensis) (Chalise, 2003) and 345 species of birds (Karki and Thapa, 2001).

\section{Materials and methods Scan Sampling}

10 minutes scan sampling was performed (as practiced by Chalise, 2003, 2009) to find out wild animals species diversity and population. It was repeated several times in each day observation with shifting of the observation site in an hour interval. It was performed in each important and significant site of proposed area.

\section{Ad libitum sampling}

A continuous recording of the data during the forest walk will be performed; whenever any new information perceived it would be recorded (Chalise, 2009).

\section{Indirect evidences collection}

The sign of Pug marks / Foot prints of animals, Droppings and marking in the trees, ground, soil, Cry, Smell or odor; Leftover food items; Trampling of plants; etc were recorded. The carcass, bones and remains of any animal parts was noted. All those noticeable evidence of the field will be recorded by camera and GPS too and filled out the format as given. The indirect evidences will be supported by the local people information generated by the participated meeting and using open questionnaire form sheet as per need.

\section{Survey Block Design}

The study area was focused on Ghodatabela to Langsisa, with an area of $25 \mathrm{~km} 2$. The study area was divided into five survey blocks, having an area of $5 \mathrm{~km}^{2}$. The study blocks had given the names as A,B,C,D and E.

\section{Snow Leopard Sign Transects}

The Snow Leopard survey was done according to SLIMS (The Snow Leopard Information Management System) developed by the International Snow Leopard Trust. The length of sign transect was $500 \mathrm{~m}$ and breadth was $5 \mathrm{~m}$ left and $5 \mathrm{~m}$ right from the center of line. The total area occupied by each sign transect was $0.5 \mathrm{~km} 2$. The sign transects were laid in ridge line, 


\section{M.K. Chalise / Our Nature (2011) 9:138-145}

crest of cliff, human footpaths, base of sloppy hills, stream bed and cliff base as the potential sites of Snow leopard. The signs (feces, scrapes and scent spraying) left by Snow Leopard were noted down. The topographic map $(1: 50,000)$ was utilized to marked the transect routes for regular observation.

\section{Identification of Pugmarks (Track survey)}

To assess the Snow Leopard status in the study area, sandy bank, and dusty footpath, muddy trail and snow covered area were surveyed. Pugmark observed in a new tracks were noted down with measurement and also recorded by photographs, digitally and also by still camera. The date, time, place, GPS recorded were also noted down.

\section{Questionnaire Survey}

Interviews from local people, hotel owner and herders were carried out within the village settlements and herders herd site in higher elevation. The Questionnaire format was meant for the information collection of presence/absence, status of the Snow Leopard, their prey species occurrences and habitat and also deal with livestock depredation by leopard. During that course outreach program based on wild animal conservation was performed among the school children, herders including local people.

\section{Results \\ Distribution}

The status and distribution of the Snow Leopard (Uncia uncia) was acquired by investigation in the field and questionnaire survey with locals. The study area (the probable habitat) was divided into five different blocks. The area of each block was $5 \mathrm{~km}^{2}$. The signs of Snow Leopard such as scrapes, scats (feces), pugmarks and scent sprays were recorded wherever possible in $25 \mathrm{~km}^{2}$. Interviews with local people, hotel owners and herders were taken in the village settlements and herder's herd site in remote Kharka (highland pasture).

From the questionnaire survey, it revealed that $90.9 \%$ respondents affirmed the occurrence of Snow Leopard in the area $(\mathrm{HH}=60)$. Local people confirmed the presence of Snow Leopard in higher elevation of Langsisa kharka, Langtang lirung, Langtang cliff, Sindum, Airport, Yala peak, Numthang, Cherkori, Nayakhang kharka, Ganjala pass and at lowest in Ghodatabela area as they have seen live animal during their domestic chorus. The study team members sighted Snow Leopard on 26 April, 2003 in Cherkori $(4570 \mathrm{~m}$ at $\left.28^{\circ} 12.598 \mathrm{~N}, 85^{\circ} 35.811 \mathrm{E}\right)$. Ninety different Snow Leopard's signs were recorded from the five blocks. Among the total sings, more signs were recorded from Cherkori kharka, Langsisa kharka, Yala peak kharka and Langtang glacier kharka. These areas consist of productive high land meadow that provides suitable habitat for Himalayan Thar, a major prey species of Snow Leopard of LNP.

Initial results show a $20-30 \%$ decline in observed Snow Leopard sign from the 2003 to 2004. It holds true except some found in 2005. However, during successive years in 2006, 2007 and 2008, it was average. Pugmarks of Snow Leopard were observed at different altitude till 2010. Urine mark and scrapes were observed during initial period while they were not seen at later. Scats and hunted remains were identified at different years. It is estimated by the different size pugmarks that at least 5-6 Snow Leopards are roaming around LNP upper area. 
M.K. Chalise / Our Nature (2011) 9:138-145

Table 1. Distribution of fecal deposits of different category according to forest type.

\begin{tabular}{|c|c|c|c|c|c|}
\hline \multirow[t]{2}{*}{ Forest types } & \multicolumn{4}{|c|}{$\begin{array}{c}\text { Droppings } \\
\text { categorization }\end{array}$} & \multirow[t]{2}{*}{ Total } \\
\hline & F1 & $\mathrm{F} 2$ & $\mathrm{O} 1$ & $\mathrm{O} 2$ & \\
\hline Betula forest & 2 & 5 & 2 & 2 & 11 \\
\hline Willow forest & 1 & 0 & 3 & 1 & 5 \\
\hline Rhododendron forest & 1 & 1 & 2 & 3 & 7 \\
\hline Mixed forest & 2 & 5 & 9 & 0 & 16 \\
\hline $\begin{array}{l}\text { Meadow+Dwarf } \\
\text { bushy forest }\end{array}$ & 3 & 1 & 2 & 0 & 6 \\
\hline Total & 9 & 12 & 18 & 6 & 45 \\
\hline
\end{tabular}

The study also showed that $20 \%$ of very fresh, $26 \%$ of fresh, $40 \%$ of old and $14 \%$ of very old fecal deposits were noticed during survey. The data shown above showed that, the best habitat for the musk deer was found to be mixed forest and Betula forest. The presence of many fecal deposits, including many fresh one, was noted in block " $\mathrm{B}$ " (not clear which one is the block "B" need to show in the map which shows that the habitat is favorable to musk deer. During our survey months, this block was almost safe from disturbances by yak, predators and human activities. But, by the end of our survey duration, human influence towards the forest increased to search Yarsa-gumba, Cordyceps sinensis (a very important herbal, animal nurtured plant) and to collect firewood. Yak-sheds were also started to shift towards this area from down elevation. According to local people, yaks are carried to high elevation during summer and carried to low elevation during winter. So, Musk deer are found to locomotive just vice-versa in order to get safe habitat. So, musk deer are found to move from 3000 to $4000 \mathrm{~m} \mathrm{msl}$, in a year. This section best fits in prey species description-musk deer section.

\section{Prey species}

The Himalayan Thar (Hemitragus jemlahicus) is the principal prey species of Snow Leopard in LNP (Khatiwada, 2004; Tiwari, 2006). Similarly, Pika (Ochotona species), Musk Deer (Moschus chrysogaster), Tibetan Snow Cock (Tetraogallus tibetatanus) and Chukor Partridge (Alectoris chukor) are other supplementary prey species found in LNP (Shrestha, 1997).

1. Musk Deer: Altogether 45 musk deer droppings sign; very fresh $(20 \%)$, fresh $(26 \%)$, old $(40 \%)$ and very old $(14 \%)$ with 12 bedding sites were recorded (Tab. 1), repetition see highlighted section. Categorization of fecal deposits was very old, old, fresh and very fresh. Study showed that population of Himalayan Musk Deer is distributed throughout the "Musk Deer Conservation Area", from Langtang village to Langsisa kharka. Only the Northern aspect of the hill showed the presence of animal than southern aspects. In between these two hills, flows the Langtang river. 45 fecal deposits were recorded of which 44 were found on north facing hill. Single deposit of very old dropping was found on south facing hill. It is because of tall and dense vegetation and it is much disturbed area due to human settlement and tourism. Out of 45 deposits of droppings, highest, 16 (35.5\%) were found in Mixed forest and lowest, $5(11.2 \%)$, were found in willow forest. Betula forest was found the most preferable forest for the bedding site. Bedding sites were made under the big caved stone by musk deer, in front of which was open and could be viewed to a far distant. It secures the musk deer from its 


\section{M.K. Chalise / Our Nature (2011) 9:138-145}

predator. Free droppings and relic sites were found more on human trail of mixed forest. It is easy for musk deer to follow human trail rather than walking away from it, through bushy places. In meadow, however, droppings were also found away from human trail as it is an open place for deer to roam around anywhere.

Musk deer, being a browser, can feed upon any type of plants in mixed forest, so fecal deposits were found in high number in mixed forest. The diet of musk deer found in LNP consists of: Betula utilis, Rhododendron campanulatum, $R$. anthopogan, $R$. setosum, willows, mosses and lichens. For summer season, deer have plenty of food items but during winter, the main diets of musk deer are lichens attached to stems, branches and stones. Other food items are fallen leaves and cones. In our survey also, we found lichens in all quadrates in abundant quantity (Pandey, 2006).

2. Himalayan Thar: Three types of Himalayan Thar herds were recognized; adult male-adult female-young $(37.5 \%)$, adult female-young $(37.5 \%)$ and all adultmale (25\%). Herd size were $23 / 2003$ and $15 / 2004$. A total of 8 herds comprising 218 individuals were recorded in the study area of $25 \mathrm{~km}^{2}$ in the Langtang valley of LNP. Population density was therefore 8.72 Thar $/ \mathrm{km}^{2}$. The average herd size was 27.25 . The herd size varied from 4 individuals to mixed herds of 48 individuals. Three types of herds were recognized; adult male-adult female-young $(37.5 \%)$, adult female and young (37.5\%) and all male (25\%). Among 8 herds three herds observed were mixed with male, female and young, three herds mixed with female and young and two male herds were also recorded during the study period. Survey revealed that $50 \%$ of the Thar herds were observed in $4200-4900 \mathrm{~m}$. This is due to less flow of tourist in the block, and there is an adequacy of sloppy grassland and steep vegetated cliffs. More over there is maximum availability of preferred food. Altogether, 218 individuals were classified to their respective sex and age classes in 2005. The average adult sex ratio was 1 male/8 adult female. Young to adult female ratio was 1 young $/ 5$ females. Himalayan Thar showed a preference towards grassland and vegetated rock in LNP. There is no marked variation in the utilization of glass land and vegetated rock (Tiwari, 2006).

\section{Threats}

High degree of habitat degradation, continuous livestock grazing, and illegal hunting of Himalayan Thar, Musk Deer, Ghoral and Snow Leopard are the major threats in that area. Local people from Langtang affirmed that Snow Leopard and its prey species used to hunt in the study area frequently. During the study periods, the researchers in the Musk Deer Conservation Area $\left(28^{\circ} 12.13^{\prime} \mathrm{N}, 8^{\circ} 33.48^{\prime} \mathrm{E}\right)$ detected 20 leg snares kept to trap musk deer and other highland wild animals. Local respondents agreed $(62.7 \%)$ about ongoing hunting of Snow Leopard itself. More than $51 \%$ local people had negative attitude towards Snow Leopard due to its livestock depredating nature. Among the total lost, high mortality of livestock was caused by predator (62\%) (Adhikari, 2004; Khatiwada, 2004).

\section{Conservation and awareness programs}

Langtang valley and its vicinity provides habitat for Snow Leopard and its prey species. But the area is under threat due to 
M.K. Chalise / Our Nature (2011) 9:138-145

heavy human encroachment and livestock grazing. The highest density of livestocks was observed above $4100 \mathrm{~m}$. The seasonal livestock grazing is prevalent in the area that affect the herbivore habitat and ultimately to survival of Snow Leopard population. The local people depend on the forest for fire wood, timber, fodder and forage. Therefore, a fierce competition between human interest and wild animal habitat utilization is stipulated in the area. The Human-Snow Leopard conflict seems tense in the Langtang valley due to livestock depredation that is means of local economy. Highlighting the importance of biodiversity and wildlife role in ecosystem, conservation education programs were launched to the schools and through the kids and teachers tried to reduce the negative aspiration of the livestock herders against the Snow Leopard. Educations outreach programs in schools were conducted till 2007 at different school at different levels along Langtang valley. Discussion with locals on conservation issues in LNP were the regular features of our team in all years. Young and adult citizens started to think more on conservation of wildlife specially Snow Leopard. Poachers' activities were exposed by locals. Two students had completed M.Sc. thesis on Snow Leopard in 2004/05 while two students completed each on Himalayan Thar and Musk Deer in 2005/06. Park rangers practiced in the field. Altogether there are more than two hundreds trained manpower due to all these training and field course program. Some of the participants are now enrolled for higher academic degree to University at Master level and Ph.D. programs in abroad. Radio and TV programs in Nepal are broadcasted and scientific and popular papers in local media were published referring the
Langtang experiences (Khatiwada and Chalise, 2006; Sharma et al., 2006).

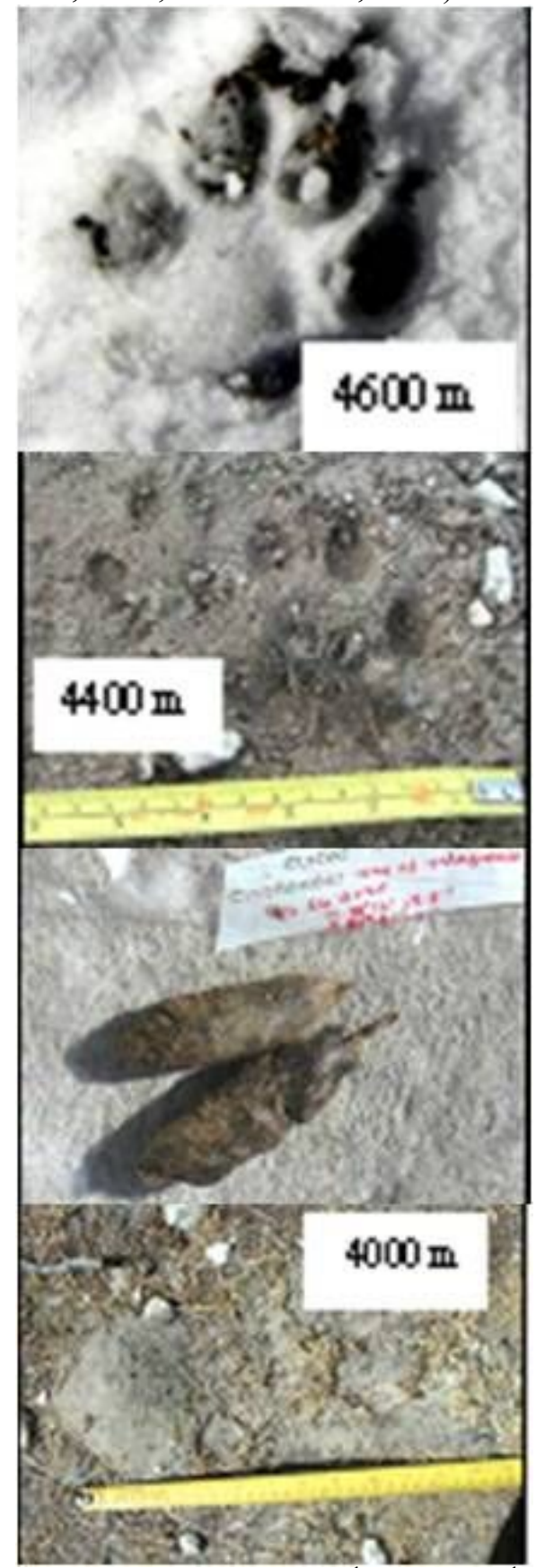

Figure 2. Pugmarks $\left(1^{\text {st }}\right.$ and $\left.2^{\text {nd }}\right)$, pellets $\left(3^{\text {rd }}\right)$ and scarp $\left(4^{\text {th }}\right)$ observed in Langtang area. 


\section{M.K. Chalise / Our Nature (2011) 9:138-145}

\section{Recent study}

After whatever possible a detail study on Snow Leopard, Musk Deer and the Himalayan Thar during early years, the author with 'Annual Conservation Biology Training Program' participants visited the study area in each successive year till 2011 at least for a week. In each session of field observation they recorded the fresh sign (pugmarks, hunted carcass, pellets and markings, etc.) of Snow Leopard (Fig.2). The local yak herders as well as late Dorje informed about the movement and presence of the species. Once in Langtang village, Dorje (local hotel owner) reported and we observed the presence of the Snow Leopard female was with two cubs near power house.

\section{Conclusion}

In Nepal, the Snow Leopards are reported in eight protected areas of the Himalayan range, however, the actual number of them in each park is not known. Computer based modeling suggest that Shey Phoksundo National Park and Annapurna Conservation Area are the only habitat that support minimally viable population of 100 or more Snow Leopard. Langu valley of Shey is said to be the density of 10-12 while in Manang 4.8-6.7 Snow Leopard/100 km² (Thapa, 2011). Our regular visit and comparison of pug marks of several numbers $(<24)$ and sizes $(<6)$ in Langtang valley suggest that there could be minimum 6 Snow Leopards in Langtang area. As once, we sighted a female with two cubs near Langtang village and a separate adult also sighted in different place around the same period reinforced us the possibility of their regular presence in the park and its estimated minimum numbers.

\section{Acknowledgements}

I like to express sincere acknowledgement with my team to the institutions, funding agencies and field assistants (Minesh, Janak, Jagannath, Mitra, Devendra, Purna, Ganga, etc.) render to complete the assessing of the Snow Leopard and its related components. Prof. R.C. Kyes, University of Washington, Seattle, is highly acknowledged on behalf of rest of team members for his pains taking effort to manage the link and funding support as well as doing research along with us for the wildlife conservation in Nepal and to initiate study of Snow Leopard in Langtang. The acknowledgement express highly to the local people/herders of Langtang, Mundu, Kyanzing and respected Lamas for kind support in the field, International Snow Leopard Trust, and Woodland Park Zoo, Seattle, WA for funding support, $\mathrm{MoF} / \mathrm{DNPWC} / \mathrm{LNP} / \mathrm{GoN}$ Nepal for permission to work, Central Department of Zoology, TU and Nepal Biodiversity Research Society, NEBORS for program logistics and initiation of projects.

\section{References}

Adhikari, J.N. 2004. Ecological study of the Snow Leopard, Uncia uncia (Schreber, 1778) in Langtang National Park. Nepal. Central Department of Zoology, T.U. 53p. (M.Sc. Thesis)

Chalise, M.K. 2003. Assamese Macaques (Macaca assamensis) in Nepal. Primate Conservation, The Journal of the IUCN/SSC Primate Specialist Group 19: 99-107.

Chalise M K. (2009). Observation of Red panda (Ailurus fulgens) in Choyatar, Ilam, East Nepal. Journal of Natural History Museum, TU, Kathmandu, Vol. 24: 97-103.

Chalise, M.K., R.C. Kyes, J. Adhikari, J. Khatiwada, M.K. Ghimire and K. Kyes 2004. A study of the status of the Snow Leopard population in Langtang National Park, Nepal. In $4^{\text {th }}$ National 


\section{M.K. Chalise / Our Nature (2011) 9:138-145}

Conference on Science and Technology, RONAST, Kathmandu. Abstract SSZ-HA-2. pp. 325.

DNPWC 2002. Langtang National Park (Booklet). Department of National Park and Wildlife Conservation, Babarmahal, Kathmandu.

Green, M.J.B. 1982. Status, distribution and conservation of the Snow Leopard in Northern India. In: International Pedigree Book of Snow Leopards (Ed. L. Blomqvist). Proceedings of a symposium, Seattle, Wa, Helsinki, Finland. 3: 610.

Karki, J.B. and B. Thapa 2001. Bird of Langtang. Langtang National park and Bird Conservation Nepal. Kathmandu. 16p.

Khatiwada, J.R. 2004. The status of Snow Leopard (Uncia uncia) and its impact on principal prey species in Langtang National Park. Central Department of Zoology, T.U., Kathmandu, Nepal. 69p. (M.Sc. Thesis)

Khatiwada, J.R. and M.K. Chalise 2006. Status of Snow Leopard and conflict perception in Kanchanjungha Conservation Area, Eastern Nepal. Nepalese Journal of Zoology 1(1): 1-8.

NAHSON 2003. Snow Leopard investigation in Langtang. Editorial, Natural History Society of Nepal, NAHSON Bulletin 12-13: 1.
Pandey, M. 2006. Status and habitat utilization of Musk Deer (Moschus chrysogaster Hodgson, 1839) in Langtang National Park, Central Nepal. Central Department of Zoology, T.U., Kathmandu, Nepal.79p. (M.Sc. Thesis)

Sharma, S., K. Thapa, M.K. Chalise, T. Dutta, Y.V. Bhatnagar and T.M. McCarthy 2006. The Snow Leopards in Himalaya: A step towards their conservation by studying their distribution, marking habitat selection, coexistence with other predators and wild prey-livestock-predator interaction. In: Conservation biology in Asia (Eds. A. Jeffrey, McNeely, T. McCarthy, A. Smith, L. Olsvig-Whittaker and E.D. Wikramanayake). Society for Conservation Biology, Asia section. pp. 184-196.

Shrestha, T.K. 1997. Mammals of Nepal (Ed. B Shrestha). Kathmandu, Nepal. 311p.

Thapa, B.B. 2011. Snow Leopard conservation in Nepal: An overview. Special issue on the occasion of $16^{\text {th }}$ Wildlife Week, 2068. Dept. of National Parks and Wildlife Cons./Govt. of Nepal. pp. 6571.

Tiwari, D.P. 2006. Status, habitat utilization and conservation of Himalayan Tahr, Hemitragus Jemlahicus (Smith, 1926) in Langtang National Park, Central Nepal. Central Department of Zoology, T.U., Nepal. 73p. (M.Sc. Thesis) 